\title{
Composition of Tree Species in Onigambari Forest Reserve, Oyo State, Nigeria
}

\section{*11HAASTRUP, NO; ${ }^{2}$ AGBOJE, I; ${ }^{1}$ LAWAL, MO; ${ }^{1}$ FADIMU, BO; ${ }^{2}$ SANGOTOYINBO, OA; ${ }^{2}$ MANGODO, C; ${ }^{3}$ ORIPELAYE, OS; ${ }^{1}$ GANIYU, OA; ${ }^{2}$ FADOYIN, AS}

\author{
${ }^{1}$ Forestry Research Institute of Nigeria, Ibadan. Oyo state, Nigeria \\ ${ }^{2}$ Federal College of Forest Resources and Management, Sakpoba. Edo State, Nigeria \\ ${ }^{3}$ Moist Forest Reserve Station, Benin. Edo State \\ *Corresponding Author Email: haastrup.no@frin.gov.ng; Tel: 08065567335
}

\begin{abstract}
The tree composition of Onigambari Forest Reserve in Oyo State was evaluated by laying out a plot size of $50 \times 50 \mathrm{~m}^{2}$ resulting to four plots per hectare. 104 and 93 stems per hectare were recorded. A total of 197 tree stands were encountered in the two compartments studied with family Sterculiaceae with species Cola gigantean, Cola millenii, Sterculia africana, Sterculia oblonga, Sterculia tragacantha, Triplochiton scleroxylon, Pterogota macrocarpa and Nesogordonia papaverifera.as the most abundant having 34 stands, followed by the family Papilionoideae with species Baphia nitida with 20 stands as the most abundance species. About thirty-nine percent of the tree species encountered were wildlings having a diameter at breast height of $\leq 10 \mathrm{~cm}$. Less than one percent $(0.50 \%)$ of the trees were of merchantable size. This could be a thing of concern and it calls for adequate resourceful and sustainable management techniques. Habits in Onigambari Forest Reserve are presented in Table 1. A total of forty-three (43) species of trees distributed into twenty (20) families were encountered. Family Sterculiaceae and Fabaceae was the richest with eight (8) species each followed by family Euphobiaceae with (5) tree species. Based on their habit, these species were classified into $100 \%$ trees. Furthermore, it is of the importance that the forest reserves be protected from illegal/indiscriminate logging among other anthropogenic activities in order to allow it regenerate.
\end{abstract}

\section{DOI: https://dx.doi.org/10.4314/jasem.v24i10.16}

Copyright: Copyright $@ 2020$ Haastrup et al. This is an open access article distributed under the Creative Commons Attribution License (CCL), which permits unrestricted use, distribution, and reproduction in any medium, provided the original work is properly cited.

Dates: Received: 15 August 2020; Revised: 22 September 2020; Accepted: 19 October 2020

Keywords: Abundance, merchantable, sustainable, resourceful

Forest reserves are portions of state lands where commercial harvesting of wood products is excluded in order to capture elements of biodiversity that can be missing from sustainably harvested sites. Forest reserve can also be described as an area of forest set aside and preserved by the government as a wilderness, national park, or the like. The forest reserves are established with a vision to protect the forests from human exploitation. The main purposes they serve are: (i) Protect the natural habitat of wildlife. (iii) Supporting reforestation by planting new trees and lots of other things in order to sustain the existence of floristic and faunas species. There are 445 gazetted forest reserves located in different parts of Nigeria. But recently this year 2020, the Finima nature park, when finally gazetted, will be Nigeria's 12th Ramsar site. Established by the Nigerian Liquefied Natural Gas Company in 2001, the park covers about 1,000 hectares. It's a mixture of tropical rain forest, mangrove swamps and freshwater ponds and is home to birds, crocodiles, snakes, alligators and the salt water hippopotamus. Only about 137 of these reserves are located in the forest region harboring the bulk of the natural forest wealth of the country (UNEP, 1992). Of the 560 species of trees present in these reserves in Nigeria, only 60 species are currently important commercially. (Nwoboshi, 1982). Adeyoju (2001) argued that global standard against deforestation was the establishment of reserves with a ratio of forest to land of $30 \%$. World Bank (2005) carried out forestry survey in Nigeria; and observed that Nigeria's remaining forest comprising reserves $(788,053 \mathrm{ha})$ and off-reserve tree $(1,854,360 \mathrm{ha})$, have been degraded. In the 1960 s, forest cover was estimated at close to 10 million hectares. By 1978, it diminished to 4 million hectares (ha). Kumar et al. (2006) noted that many forests are under great human pressure and require urgent intervention to maintain the overall biodiversity, productivity and sustainability. The intricacy and rich diversity of life found in forests provides important services to human beings. Moreover, humans are destroying forest biodiversity at an alarming rate. Singh et al., 2002 described biodiversity as the aggregate of genes, species and ecosystem in a particular location. It is useful for human survival and economic well-being and for the 
ecosystem productivity and balance. Walker (1992) and Purvis et al., 2000 indicated that the concept of biodiversity is considered to be the integration of biological difference across all scales, from genetic level, through species and ecosystems, to the landscape that they present, or are part of, and the ecological processes that works with them. The purpose of this work therefore is to evaluate the effects of such uncontrolled exploitation on the tree population of Onigambari Forest Reserve. The purpose of this work therefore is to evaluate the effects of such uncontrolled exploitation on the tree population of Onigambari Forest Reserve situated in Oyo State of Nigeria.

\section{MATERIALS AND METHODS}

Study Location: Onigambari Forest Reserve lies on latitude $7^{\circ} 8^{1} \mathrm{~N}$ and $7^{\circ} 3^{1} \mathrm{~N}$ longitude $3^{\circ} 49^{1} \mathrm{E}$ and $3^{\circ}$ $22^{1} \mathrm{E}$ (Fig 3.1). The plot lies within $17 \mathrm{~km}$ South-east of Ibadan on the Idi-Ayunre-Ijebu-Ode road, Oyo State. It was laid about $2 \mathrm{~km}$ away from the nearest road well obscured by some forest fallows in the neighborhood. The Onigambari Forest Reserve was declared from Ibadan Forest Reserve by a resolution of the Ibadan city council passed in September 1899 (Ajibode, 2002). Two sections were consolidated to form a Forest Reserve in 1953 making a total area of $125.62 \mathrm{~km}^{2}$ (Ajibode, 2002). Hence tree like Teak (Tectona spp), Mahogany (Khaya ivorences), and other Agricultural crops like cocoa (Theobroma cacao), cassava (Manihot spp) with exotic trees and crops were cultivated. The inhabitants of the area are predominantly farmers with relatively low number of hunters (Ajibode et al., 2002). Some of the forestry practice includes; Planting of trees for both timber and fuel wood production; Collection and sales of non-wood products such as leaves and bark for herbs, rattan (cane), One of the main feature of this forest is that most of the plants, climbers and epiphytes are woody and of the sizes of trees. There is an outstanding diversity of flora and fauna.

Survey method: Systematic line transect was employed for the laying of plots in the unlogged and logged forest sites. Two transects with a distance of $500 \mathrm{~m}$ between them was laid at the centre of each site. A sample plot of equal size $(50 \mathrm{~m} \times 50 \mathrm{~m})$ was laid in alternate direction resulting into four plots and a total of 8 sample plots for the study sites. Using this method ensured that the forest is relatively covered.

The botanical name of every living tree that was encountered in each sample plot was recorded for the study site and their girths at breast height were measured. Where a tree's botanical name was not known immediately, such a tree was identified by its commercial or local name. Such commercial or local names were translated to correct botanical names using Gbile (1984) and Keay (1989). Trees that could not be identified were tagged 'unknown'. Specimens of such unknown trees were collected and preserved in a wooden press and taken to Forestry Herbarium, Ibadan (FHI) of the Forestry Research Institute of Nigeria for their identification. From the raw data obtained from the floristic enumeration and survey, the following vegetation attributes were extracted.

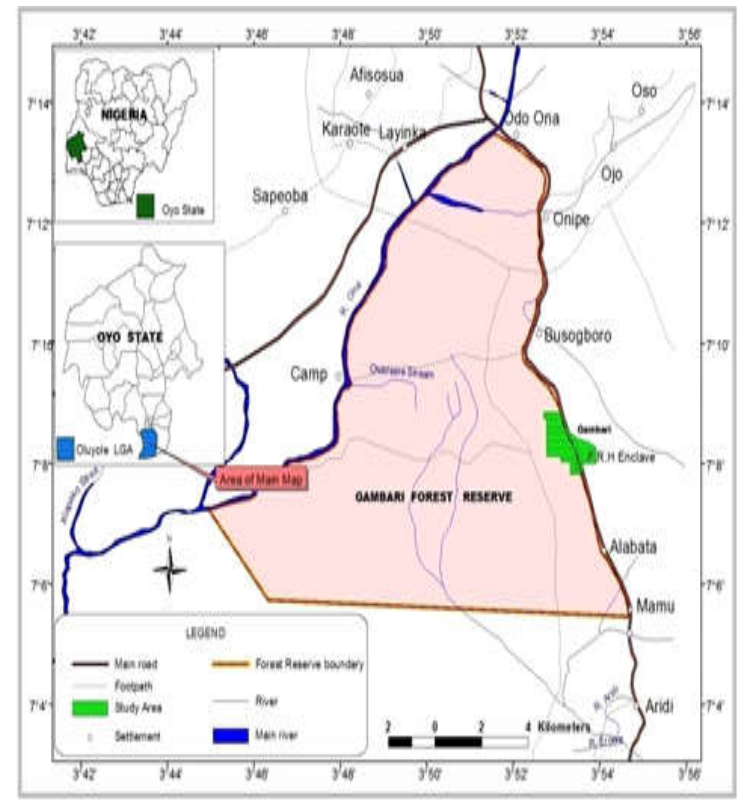

Fig 1: Map of Onigambari Forest Reserve

Analysis of field data: The following parameters were studied (a) Relative diversity which is the number of species in each family represented. (b) Diameter at breast Height using the formula

$$
\frac{\text { Girth }}{\pi}
$$

Where л is a constant of 3.142

\section{RESULTS AND DISCUSSION}

A catalogue of the trees species, their families, and habits in Onigambari Forest Reserve are presented in Table 1. A total of forty-three (43) species of trees distributed into twenty (20) families were encountered. Family Sterculiaceae and Fabaceae was the richest with eight (8) species each followed by family Euphobiaceae with (5) tree species. Based on their habit, these species were classified into $100 \%$ trees. Table 2 presents the result of the various diameter class sizes and Figure 2.presents the 197 stands encountered in the study. 78 were in the diameter class of $\leq 10 \mathrm{~cm}$ which amount to about $39.59 \%$ of the total trees encountered. 
Table1: Tree species, Habits and families represented at Onigambari Forest Reserve

\begin{tabular}{|c|c|c|}
\hline FAMILIES & SPECIES & Habit \\
\hline \multirow{3}{*}{ Apocynaceae } & Funtumia elastic & Tree \\
\hline & Astonia booneii & Tree \\
\hline & Aningeria robusta & Tree \\
\hline Boraginaceae & Cordia millenii & Tree \\
\hline Capparaceae & Boscia angustifolia & Tree \\
\hline Combretaceae & Terminalia superba & Tree \\
\hline Caesalpinioideae & Erythrophylleum ivorensis & Tree \\
\hline \multirow[t]{3}{*}{ Clusiaceae } & Allanblackia floribunda Oliv. & Tree \\
\hline & Garcinia kola Heckel & Tree \\
\hline & Pentadesma butyracea Sabine & Tree \\
\hline \multirow[t]{5}{*}{ Euphobiaceae } & Bridelia micrantha & Tree \\
\hline & Ricinodendron heudelotii & Tree \\
\hline & Diospyros alboflavescens & Tree \\
\hline & Diospyros dendo & Tree \\
\hline & Diospyros mesipiliformis & Tree \\
\hline \multirow[t]{8}{*}{ Fabaceae } & Gossweilorodendron balsaminiferum & Tree \\
\hline & (Verm.) Harms Guibourtia sp. Benn. & Tree \\
\hline & Hymenostegia afzelii (Oliv.) Harms & Tree \\
\hline & $\begin{array}{l}\text { Lonchocarpus griffonianus (Baill.) } \\
\text { Dunn. }\end{array}$ & Tree \\
\hline & $\begin{array}{l}\text { Pachyelasma tessmannii (Harms) } \\
\text { Harms }\end{array}$ & Tree \\
\hline & Pentaclethra macrophylla Benth. & Tree \\
\hline & Piptadeniastrum africanum (Hook F.) & Tree \\
\hline & Brenan Pterocarpus osun Craib & Tree \\
\hline Leguminoseae & Daniellia ogea & Tree \\
\hline Maliaceae & Trichilia monadelpha & Tree \\
\hline \multirow[t]{2}{*}{ Mimosoideae } & Albizia zygia & Tree \\
\hline & Piptadeniastrum africanum & Tree \\
\hline Moraceae & Treculia Africana & Tree \\
\hline Myristicaceae & Pycnanthus angolensis & Tree \\
\hline Olacaceae & Strombosia pustulata & Tree \\
\hline Papilionoideae & Baphia nitida & Tree \\
\hline Phyllanthaceae & Bridelia micrantha & Tree \\
\hline \multirow[t]{2}{*}{ Rutaceae } & Fagara macropylia & Tree \\
\hline & Fagara zanto & Tree \\
\hline Sapotaceae & Chrysophyllum albidum & Tree \\
\hline \multirow{7}{*}{ Sterculiaceae } & Cola gigantean & Tree \\
\hline & Cola millenii & Tree \\
\hline & Sterculia Africana & Tree \\
\hline & Sterculia oblonga & Tree \\
\hline & Sterculia tragacantha & Tree \\
\hline & Triplochiton scleroxylon & Tree \\
\hline & Nesogordonia papaverifera & Tree \\
\hline Ulmaceae & Celtis zenkeri & Tree \\
\hline
\end{tabular}

This was followed by the diameter class of $10-20 \mathrm{~cm}$ with 50 stands which is $25.38 \%$ of tree population in the reserve. The diameter class of $91-100$ cmand 100> had the least stand of 1 with about $0.51 \%$ each.

Relative diversity: The families Fabaceae and Sterculiaceae has the highest diversity of eight species each according to this study carried out in Onigambari Forest Reserve, Oyo State in South-West Nigeria. Similar quantity was recorded in the report of Haastrup et al (2018) when they carried out a study on the effect of logging on diversity of forest trees. Euphobiaceae comes next after Fabaceae and Sterculiaceae with five spp; Apocynaceae and Clusiaceae with three spp. each. Mimosoideae and Rutaceae had two.

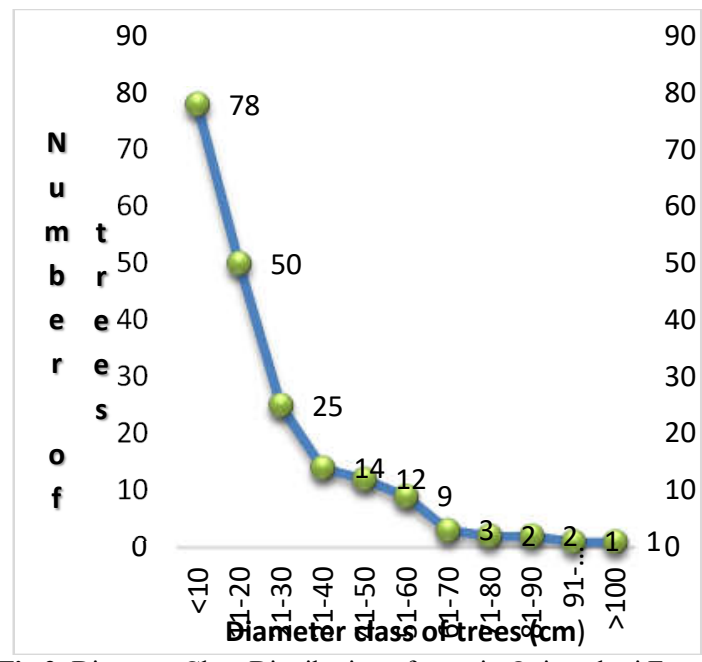

Fig 2: Diameter Class Distribution of trees in Onigambari Forest Reserve

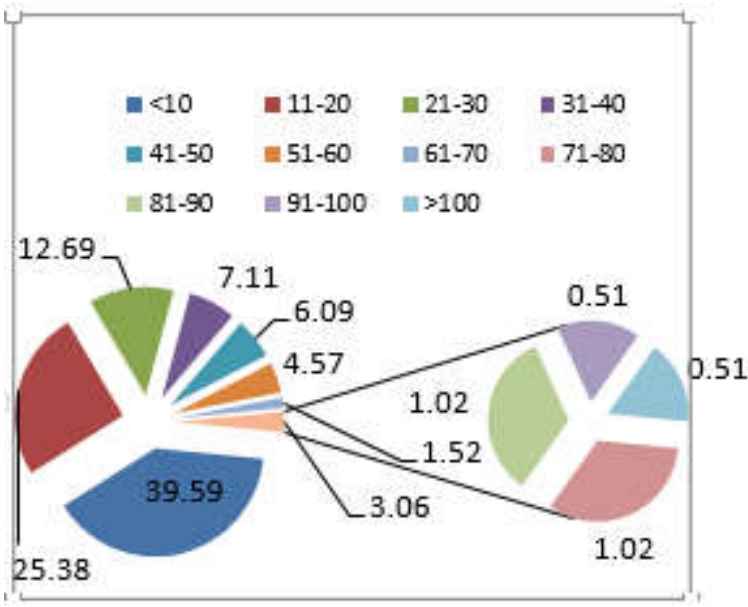

Fig 3: Percentage Distribution of stem diameter classes $\leq 10 \mathrm{~cm}$ in Onigambari Forest Reserve, Oyo State

Table 2: Percentage distribution of the various diameter class sizes

\begin{tabular}{lll}
\hline $\begin{array}{c}\text { Diameter } \\
\text { class }(\mathrm{cm})\end{array}$ & $\begin{array}{l}\text { Number } \\
\text { of trees }\end{array}$ & $\begin{array}{l}\text { Percentage } \\
\text { Proportion }\end{array}$ \\
\hline$\leq 10$ & 78 & 39.59 \\
$11-20$ & 50 & 25.38 \\
$21-30$ & 25 & 12.69 \\
$31-40$ & 14 & 7.11 \\
$41-50$ & 12 & 6.09 \\
$51-60$ & 9 & 4.57 \\
$61-70$ & 3 & 1.52 \\
$71-80$ & 2 & 1.02 \\
$81-90$ & 2 & 1.02 \\
$91-100$ & 1 & 0.51 \\
$>100$ & 1 & 0.51 \\
Total & $\mathbf{1 9 7}$ & $\mathbf{1 0 0}$ \\
\hline
\end{tabular}

These serves as the most occurring/dominant families represented in the study area. Moksia et al. (2012) and Sawadogo et al. (2007) reported that families Combretaceae and Sterculiaceae were the most dominant families in Kalfou forest Reserve in Cameroon and Togo forest in Burkina Faso 
respectively which are also in Savannah region. Dispersal of seeds might be a contributing factor to the dominace or occurrence of some species in family than the others. This of course is as a result of a conducive environment where the seeds are been dispersed far away from the mother tree. And a situation where there is competition for survival, only the strongest will adapt and survive.

The dominance of Fabaceae and Meliaceae in Olokemeji Forest Reserve reported by Ogunleye et al. (2004) was because of easy wind dispersal which consolidates their spread in the study location. On the contrary, twelve families within the study site of the Forest Reserve had poor species diversity. Each of the family had only one species. This could be accredited to anthropogenic activities like illegal logging. Salami et al (2006) reported that the current concern in the environment stems from evidence that natural processes are being disrupted by uncontrollable /unproductive means of forest extraction.

Diameter at breast height (dbh): The result of the dbh $(\mathrm{m} / \mathrm{ha})$ for the forest showed that the highest $\mathrm{dbh}$ ( $\mathrm{m} / \mathrm{ha}$ ) respectively belonging to the family Fabaceae and Sterculiaceae. About fourty percent of the trees encountered were in the diameter class of $\leq 10 \mathrm{~cm}$. This is in accordance with the findings of Adekunle et al. (2004) in the moist forest of South Western Nigeria. Also, Oduwaiye et al. (2002) reported that all plots studied by them had the largest number of trees in the smallest diameter class of below $10 \mathrm{~cm}$ at the Okomu permanent sample plots.

It was also reported that the smallest number of trees in the diameter class of $25-30 \mathrm{~cm}$. Only one stand was found in the diameter class of $91-100 \mathrm{~cm}$ and $>100 \mathrm{~cm}$ in the study at Onigambari Forest Reserve. There has been constant felling of both timber and fuel trees in Onigambari Forest Reserve and it calls for grave concern and for the trend in order for sustainability of the forest trees.

Conclusion: Composition of Tree Species in Onigambari Forest Reserve, Oyo State, Nigeria was established in this study. The composition in Onigambari Forest Reserve was sparsely populated with tree species. The species distribution pattern of the study area indicates that the forest is characterized by a uniform distribution of individual tree species. The low stem density obtainable in logged area is an evidence of the degree of devastation the forest has been subjected to due to human interference. This calls for an urgent solution so as devastating loss of these tree species particularly those already threatened into extinction.

\section{REFERENCE}

Adekunle, VAJ; Akindele, SO; Fuwape, JA (2004). Structure and yield models of tropical lowland rainforest ecosystem of southwest Nigeria. Food. Agric. Environ. 2 (2) 395-399.

Adeyoju, SK (2001). Forestry for National Development: a critique of the Nigeria situation in Popoola L; Abu JE; Oni PI (editors) Forestry and National Development. Proceedings of the 27th Annual Conference of the F.A.N. Abuja Nigeria pp 54-68.

Ajibode, MO (2002). Wood species composition and regeneration potential of Onigambari Forest Reserve, Oyo state. A project submitted to the Department Forestry and Wildlife Management FUNNAB Pp.18.

Gbile, ZO. (1984): Vernacular Names of Nigerian Plants-Yoruba. - Forestry Research Institute of Nigeria, Ibadan, Nigeria.

Haastrup, NO; Oke, SO. (2018): Effect of Logging on Diversity and Abundance of Tree Species in Onigambari Forest Reserve, Oyo State, Nigeria. Inter. J. Appl. Res. Tech. 7, 10, 45 - 51.

James, W. (1992): Human resource strategy New York: McGraw Hill, pp. 378 pages, ISBN 007 0678464

Keay, RWJ.(1989): Trees of Nigeria. - A revised version of "Nigeria Trees" (Keay, et al., 1964) Clarendron Press, Oxford. pp.476.

Kumar A; Marcot, BG; Saxena A (2006). Tree species diversity and distribution patterns in tropical forests of Garo Hills. Cur. Sci. 91: 1370-1381

Nwoboshi, LC (1982): Tropical Silviculture. Ibadan University Press. Ibadan; p333

Oduwaiye, EA; Oyeleye, B; Oguntala, AB (2002): Species Diversity and Potentiality for Regeneration in Okomu Permanent Sample Plot. - In: Forestry and Challenges of Sustainable Livelihood, Abu, J.E., Oni, P.I., Popoola, L. (eds) Proceeding of the $28^{\text {th }}$ Annual Conference of the Forestry Association of Nigeria, Akure, Nigeria. 4th-8th Nov.2002, pp. 264-271.

Ogunleye, AJ; Adeola, AO; Ojo, LO; Aduradola, AM (2004). Impact of Farming activities on Vegetation of Olokemeji Forest Reserve, Nigeria, Global Nest: the Inter. J. 6(2): 130-139.

HAASTRUP, NO; AGBOJE, I; LAWAL, MO; FADIMU, BO; SANGOTOYINBO, OA; MANGODO, C; ORIPELAYE, OS; GANIYU, OA; FADOYIN, AS 
Purvis, A; Agapow, PM; Gittleman, JL; Mace, GM. (2000). Nonrandom extinction risk and the loss of evolutionary history. Sci. 288. 328-330.

Salami, AT; EE Balogun (2006), Monitoring Deforestation and Implications for Biodiversity in Nigeria Using Data from NigeriaSat-1 and other Satellites, A Project Report Submitted to National Space Research and Development Agency (NASRDA), Federal Ministry of Science and Technology, Abuja.

Ayobami, T.S. Sawadogo P; Tigabu, M; Sawadogo, L; Oden PC (2007). Woody species composition, structure and diversity of vegetation patches of a Sudanian Savanna in Burkina Faso, Bois et Forets des Tropiques 294(4):5-20.
Singh, JS; Khurana, E (2002). Proc. Indian Natl. Sci. Acad., B68 in press.

UNEP- United Nations Environment Programme (1992) Biological Diversity in Nigeria- A country study. 53p.

World Bank (2005): Elements of Strategy for Forest Reform: World Agro Forestry Center, Phase 1Report No. 27323. 